\title{
PENGARUH MANAJEMEN RISIKO KREDIT TERHADAP KINERJA PT BANK PERKREDITAN RAKYAT SUMATERA SELATAN PERIODE 2015 - 2019
}

\author{
Faitullah $^{1}$, Muhammad Alfan Nurrachman ${ }^{2}$ \\ Sekolah Tinggi Ilmu Ekonomi Mulia Darma Pratama \\ E-mail : anang,faitullah@gmail.com ${ }^{1}$, vahnrudess@ gmail.com ${ }^{2}$
}

\begin{abstract}
Abstrak
Pengaruh manajemen risiko kredit terhadap kinerja PT Bank Perkreditan Rakyat Sumatera Selatan periode 2015 - 2019. Rumusan masalah dalam penelitian ini adalah bagaimana pengaruh manajemen risiko kredit terhadap kinerja PT Bank Perkreditan Rakyat Sumatera Selatan. Penelitian ini bertujuan untuk mengetahui pengaruh manajemen risiko kredit terhadap kinerja PT Bank Perkreditan Rakyat Sumatera Selatan. Metode penelitian menggunakan metode kuantitatif. Metode analisis data yang digunakan adalah deskriptif. Berdasarkan hasil penelitian menunjukkan bahwa pengaruh manajemen risiko kredit terhadap kinerja PT Bank Perkreditan Rakyat Sumatera Selatan periode 2015 - 2019 yang diukur melalui PPAP bahwa PPAP berpengaruh terhadap pendapatan BPR, yaitu pada tahun 2015 - 2017 dengan meningkatnya PPAP maka pendapatan berkurang dan pada tahun 2018 2019 dengan menurunnya PPAP maka pendapatan meningkat.
\end{abstract}

Kata kunci : manajemen risiko, risiko kredit, kinerja

\section{Abstract}

The effect of credit risk management on the performance of PT Bank Perkreditan Rakyat South Sumatra for the period 2015 - 2019. The problem formulation in this study is how the effect of credit risk management on the performance of PT Bank Perkreditan Rakyat South Sumatra. This study aims to determine the effect of credit risk management on the performance of PT Bank Perkreditan Rakyat South Sumatra. The research method uses quantitative methods. The data analysis method used is descriptive. Based on the results of the study, it shows that the effect of credit risk management on the performance of PT Bank Perkreditan Rakyat South Sumatra for the period 2015 - 2019 as measured through PPAP shows that PPAP has an effect on BPR income, namely in 2015 - 2017 with the increase in PPAP, the income is reduced and in 2018 - 2019 with decreasing PPAP, income increases.

Key words: risk management, credit risk, performance

\section{PENDAHULUAN}

Situasi lingkungan eksternal dan internal perbankan mengalami perkembangan pesat yang diikuti dengan semakin kompleksnya risiko kegiatan usaha perbankan sehingga meningkatkan kebutuhan praktek tata kelola Bank yang sehat (Good Corporate Governance) dan penerapan manajemen risiko yang meliputi pengawasan aktif pengurus Bank, kebijakan, prosedur dan penetapan limit risiko, proses identifikasi, pengukuran, pemantauan, sistem informasi, dan pengendalian risiko, serta sistem pengendalian intern (Riska, 2013:14).
Penerapan manajemen risiko tersebut akan memberikan manfaat, baik kepada perbankan maupun otoritas pengawasan Bank. Bagi perbankan, penerapan manajemen risiko dapat meningkatkan shareholder value, memberikan gambaran kepada pengelola Bank mengenai kemungkinan kerugian Bank di masa datang, meningkatkan metode dan proses pengambilan keputusan yang sistematis yang didasarkan atas ketersediaan informasi, digunakan sebagai dasar pengukuran yang lebih akurat mengenai kinerja Bank, digunakan untuk menilai risiko yang melekat pada instrumen atau 
kegiatan usaha Bank yang relatif kompleks serta menciptakan infrastruktur manajemen risiko yang kokoh dalam rangka meningkatkan daya saing Bank. Bagi otoritas pengawasan Bank, penerapan manajemen risiko akan mempermudah penilaian terhadap kemungkinan kerugian yang dihadapi Bank yang dapat mempengaruhi permodalan Bank dan sebagai salah satu dasar penilaian dalam menetapkan strategi dan fokus pengawasan Bank (Riska, 2013:16).

Esensi dari penerapan manajemen risiko adalah kecukupan prosedur dan metodologi pengelolaan risiko sehingga kegiatan usaha Bank tetap dapat terkendali (manageable) pada batas / limit yang dapat diterima serta menguntungkan Bank. Namun demikian mengingat perbedaan kondisi pasar dan struktur, ukuran serta kompleksitas usaha Bank, maka tidak terdapat satu sistem manajemen risiko yang universal untuk seluruh Bank sehingga setiap Bank harus membangun sistem manajemen risiko sesuai dengan fungsi dan organisasi manajemen risiko pada Bank (Wildah, 2014:44).

Setelah dilakukan identifikasi risiko secara akurat, selanjutnya secara berturutturut Bank perlu melakukan pengukuran, pemantauan dan pengendalian risiko. Pengukuran risiko tersebut dimaksudkan agar Bank mampu mengkalkulasi eksposur risiko yang melekat pada kegiatan usahanya sehingga Bank dapat memperkirakan dampaknya terhadap permodalan yang seharusnya dipelihara dalam rangka mendukung kegiatan usaha dimaksud. Sementara itu, dalam rangka melaksanakan pemantauan risiko, Bank harus melakukan evaluasi terhadap eksposur risiko, terutama yang bersifat material dan atau yang berdampak pada permodalan Bank (Djohanputro, 2008:96).

Hasil pemantauan yang mencakup evaluasi terhadap eksposur risiko tersebut dilaporkan secara tepat waktu, akurat dan informatif yang akan digunakan oleh pihak pengambilan keputusan dalam suatu Bank, termasuk tindak lanjut yang diperlukan.
Selanjutnya berdasarkan hasil pemantauan tersebut, Bank melakukan pengendalian risiko antara lain dengan cara penambahan modal, lindung nilai, dan teknik mitigasi risiko lainnya. Kegiatan usaha Bank senantiasa dihadapkan pada risiko bisnis yang berkaitan erat dengan pengelolaan usahanya sebagai perantara keuangan. Sejalan dengan perkembangan dunia usaha, risiko bisnis yang dihadapi juga berkembang secara luas yang antara lain mencakup risiko kredit, risiko pasar, risiko likuiditas, risiko operasional, risiko hukum, dan lain sebagainya. Dalam rangka meminimalisir risiko kerugian, Bank wajib melaksanakan transaksi tersebut dengan berpedoman pada kebijakan dan prosedur penerapan manajemen risiko yang ditetapkan dengan berlandaskan pada prinsip kehati-hatian (Djohanputro, 2008:103).

Salah satu risiko adalah risiko kredit. Risiko kredit merupakan risiko yang paling signifikan dari semua risiko yang menyebabkan kerugian potensial khususnya di perbankan. Risiko kredit adalah risiko yang terjadi karena kegagalan debitur yang menyebabkan tak terpenuhinya kewajiban untuk membayar hutang sehingga risiko kredit adalah masalah yang harus mendapat perhatian khusus dari bank karena setiap rupiah kredit yang tidak dapat dibayarkan akan menimbulkan suatu kredit yang bermasalah. Kredit bermasalah tersebut dapat menurunkan kinerja perbankan dan berpotensi menimbulkan kerugian bagi bank. Kerugian yang akan terjadi dapat diantisipasi dengan manajemen risiko. Manajemen risiko adalah proses sistematik untuk mengelola risiko. Tujuan manajemen risiko bukan menghindari risiko, tetapi mengidentifikasi, mengevaluasi, dan mengendalikan risiko (Dwi, 2011:78).

PT Bank Perkreditan Rakyat Sumatera Selatan (PT BPR Sumsel) adalah salah satu dari dua BUMD di Provinsi Sumatera Selatan di bidang perbankan. Berdiri tanggal 21 Januari 2008, PT BPR Sumsel memiliki laporan keuangan 
berkembang setiap tahunnya namun tidak sebanding dengan kinerja kredit dalam beberapa tahun terakhir.

Berdasarkan informasi yang didapatkan dari laporan keuangan publikasi PT Bank Perkreditan Rakyat Sumatera Selatan tahun 2015 - 2019, terjadi fenomena dimana tingkat kredit bermasalah pada PT Bank Perkreditan Rakyat Sumatera Selatan mengalami fluktuasi dalam lima tahun terakhir. Hal ini tidak terlepas dari beberapa faktor, diantaranya kurang gencarnya penyaluran kredit, analisa kredit yang kurang maksimal, penyaluran kredit tanpa memperhatikan asas kehati - hatian, dll. Faktor - faktor risiko kredit inilah yang menjadi faktor risiko yang berkaitan dengan kinerja dan memiliki korelasi dengan manajemen risiko pada PT Bank Perkreditan Rakyat Sumatera Selatan yang akan diteliti oleh peneliti dan hal inilah juga yang menarik minat peneliti untuk melakukan penelitian dan menganalisa apakah terdapat pengaruh yang signifikan penerapan manajemen risiko kredit terhadap kinerja laba PT Bank Perkreditan Rakyat Sumatera Selatan.

Penelitian tentang penerapan manajemen risiko terhadap kinerja keuangan telah dilakukan oleh beberapa peneliti sebelumnya. Penelitian yang dilakukan oleh Caya (2010:77) menunjukan bahwa pengaruh penerapan manajemen risiko perbankan terhadap pemberian kredit menunjukkan hasil yang signifikan. Poudel (2012:102) menemukan bahwa manajemen risiko kredit yang diukur dengan default rate yang diproksikan dengan non performing loan (NPL) berpengaruh negatif signifikan terhadap kinerja yang berarti bahwa manajemen risiko akan berpengaruh positif pada kinerja keuangan. Hal serupa juga diungkapkan oleh Attar dkk, (2014:115) dalam penelitiannya menemukan bahwa penerapan manajemen risiko kredit dan manajemen risiko operasional berpengaruh positif dan signifikan terhadap kinerja keuangan (ROA dan ROE). Sedangkan penerapan manajemen likuiditas berpengaruh positif terhadap kinerja keuangan diukur dengan ROA, dan berpengaruh negatif terhadap kinerja keuangan yang diukur dengan ROE.

Berdasarkan uraian dalam latar belakang sebelumnya, maka permasalahan dalam penelitian ini adalah: "Bagaimana pengaruh manajemen risiko kredit terhadap kinerja PT Bank Perkreditan Rakyat Sumatera Selatan periode 2015 - 2019?”

\section{METODOLOGI PENELITIAN}

\subsection{Risiko Kredit}

Risiko kredit adalah risiko kerugian yang diderita bank, terkait kemungkinan bahwa pada jatuh tempo, counterparty-nya gagal memenuhi kewajiban - kewajiban kepada bank (Ali, 2006:20). Risiko kredit dapat diukur dengan metode Value at Risk (VaR). VaR dapat mengetahui berapa jumlah risiko maksimum yang akan dialami bank.

\subsection{Kinerja Keuangan}

Kinerja keuangan, dalam hal ini kinerja keuangan perbankan adalah suatu gambaran sampai mana tingkat keberhasilan yang dicapai oleh bank dalam kegiatan operasionalnya (Astri, 2006:44). Dalam hal penelitian ini, kinerja yang diukur adalah PPAP dan kemudian membandingkan dengan seberapa besar pengaruh terhadap laba bank.

\section{METODE PENELITIAN}

Metode penelitian dalam penelitian ini adalah kuantitatif. Metode kuantitatif adalah metode yang menunjukkan hubungan sebab dan akibat antara dua variabel atau lebih. Tujuan dari penelitian ini yaitu untuk melihat pengaruh suatu variabel terhadap variabel lainnya.

\section{Metode Analisis Data}

Metode analisis data dalam penelitian ini adalah analisis deskriptif. 
Analisis deskriptif adalah metode yang digunakan untuk menganalisis data dengan cara mendeskripsikan atau menggambarkan data yang telah dikumpulkan sebagaimana adanya tanpa bermaksud membuat kesimpulan yang berlaku untuk umum atau generalisasi (Sugiyono, 2019:206). Untuk menjawab rumusan masalah yang telah dirumuskan sebelumnya, adapun langkah langkahnya adalah sebagai berikut:

\section{Identifikasi Risiko Kredit}

Tahapan ini dimulai dengan mengidentifikasi risiko kredit, dibagi menjadi profil produk kredit dan karakteristik debitur. Keduanya akan dihubungkan dengan kolektibilitas kredit berdasarkan Peraturan Bank Indonesia No. 8/9/PBI/2009 tentang Kualitas Aktiva Produktif (KAP) yang meliputi:

1. Lancar (L)

Kredit yang tidak terdapat tunggakan angsuran pokok dan atau bunga tidak lebih dari tiga kali angsuran dan kredit belum jatuh tempo.

2. Kurang Lancar (KL)

Kredit yang terdapat tunggakan pokok dan atau bunga lebih dari tiga kali angsuran tetapi tidak lebih dari enam kali angsuran; kredit telah jatuh tempo tidak lebih dari satu bulan.

3. Diragukan (D)

Kredit yang terdapat tunggakan angsuran pokok dan atau bunga lebih dari enam kali angsuran tetapi tidak lebih dari 12 kali angsuran; kredit telah jatuh tempo lebih dari satu bulan tetapi tidak lebih dari dua bulan.
Kredit yang terdapat tunggakan angsuran pokok dan atau bunga lebih dari 12 kali angsuran; kredit telah jatuh tempo lebih dari dua bulan; kredit telah diserahkan kepada Badan Urusan Piutang Negara (BUPN); kredit telah diajukan pengganti ganti rugi kepada perusahaan asuransi kredit.

Selanjutnya dibuatkan tabel

NPL (Non Performing Loan) yang berisi nilai persentase dari profil produk kredit dan karakteristik debitur.

\section{Analisis Risiko Kredit}

\section{- Value at Risk (VaR)}

Salah satu alat analisis yang digunakan untuk menghitung risiko kredit adalah VaR. VaR dapat mengetahui berapa jumlah risiko maksimum yang akan dialami bank. Tahap menghitung $\mathrm{VaR}$ adalah sebagai berikut:

1. Menentukan matriks transisi tahunan

Matriks transisi bulanan merupakan rating debitur baik, meningkat, menutun atau tetap (perubahan dari migrasi kualitas kredit pada suatu periode waktu tertentu). Matriks transisi ini berukuran 4 x 4 karena jumlah kelas (grade) dalam credit rating system ada empat yaitu lancar, kurang lancar, diragukan, dan macet.

2. Menentukan matriks migrasi unconditional

Matriks migrasi unconditional adalah proporsi perpindahan kolektibilitas satu bulan ke bulan berikutnya. Bentuk matriks ini sama dengan matriks transisi.

4. Macet $(\mathrm{M})$

\begin{tabular}{l|llll}
\multicolumn{1}{c}{} & \multicolumn{1}{c}{$\mathrm{L}$} & $\mathrm{KL}$ & $\mathrm{D}$ & $\mathrm{M}$ \\
\cline { 2 - 5 } $\mathrm{L}$ & $\mathrm{P}_{11}$ & $\mathrm{P}_{12}$ & $\mathrm{P}_{13}$ & $\mathrm{P}_{14}$ \\
$\mathrm{KL}$ & $\mathrm{P}_{21}$ & $\mathrm{P}_{22}$ & $\mathrm{P}_{23}$ & $\mathrm{P}_{24}$ \\
$\mathrm{D}$ & $\mathrm{P}_{31}$ & $\mathrm{P}_{32}$ & $\mathrm{P}_{33}$ & $\mathrm{P}_{34}$ \\
$\mathrm{M}$ & $\mathrm{P}_{41}$ & $\mathrm{P}_{42}$ & $\mathrm{P}_{43}$ & $\mathrm{P}_{44}$
\end{tabular}


Baris ke satu pada matriks di atas merupakan peluang untuk menghitung VaR pada kolektibilitas lancar. Baris ke dua merupakan peluang untuk menghitung VaR pada kolektibilitas kurang lancar, dan seterusnya. Keterangan:

a. P11 adalah peluang kredit dengan peringkat 1 (kolektibilitas lancar) tetap berada pada peringkat 1 (kolektibilitas lancar).

b. P12 adalah peluang kredit dengan peringkat 1 (kolektibilitas lancar) menjadi berada pada peringkat 2 (kolektibilitas kurang lancar) dan seterusnya. c. L, KL, D, dan M adalah kolektibilitas lancar, kurang lancar, diragukan, dan macet.

3. Menghitung rata-rata nilai baki debet

Rata - rata nilai ini merupakan jumlah dari hasil perkalian antara peluang migrasi ke peringkat tertentu dengan hasil kali antara nilai baki debet total peringkat tertentu pada akhir periode pengamatan dengan peluang peringkat tertentu. Peringkat yang dimaksud adalah kolektibilitas. Secara sistematis dapat dirumuskan sebagai berikut:

$$
\mu_{\text {total }}=\sum_{\mathrm{i}}^{\mathrm{s}}=1 \mathrm{pi} \mu \mathrm{i}
$$

Keterangan:

a. $\mu$ total adalah rata-rata nilai baki debet

b. pi adalah peluang suatu kondisi ( peluang migrasi ke peringkat tertentu) dari L ke L, L ke KL, L ke D, L ke M. Dari KL ke L, KL tetap KL, KL ke D, KL ke M, dan seterusnya

c. $\mu$ i adalah nilai baki debet yang merupakan hasil kali antara baki debet total dengan peringkat tertentu pada akhir periode

$$
\delta^{2}=\sum_{i=0}^{s} p i \mu i^{2}-\mu_{\text {total }}^{2}
$$

6. Menghitung simpangan baku yang merupakan akar dari ragam. Simpangan baku disebut volatilitas. Nilai volatilitas digunakan untuk

\section{$\mathrm{VaR}=\mathrm{Z} \alpha \times \delta$}

Keterangan:

a. $Z \alpha$ adalah titik ktitik pada tabel $\mathrm{Z}$ (Z $\alpha$ pada tingkat keyakinan tertentu)

b. $\delta$ adalah pendugaan volatilitas

Semakin besar tingkat kepercayaan yang digunakan maka nilai $\mathrm{VaR}$ pengamatan dengan peluang peringkat tertentu

d. s adalah banyaknya peringkat (L, KL, D, M)

4. Menghitung selisih nilai baki debet dengan nilai rata-rata debet ( $\mu$ total)

5. Menghitung ragam, yaitu jumlah dari hasil rata-rata perkalian kuadrat selisih rata-rata nilai baki debet dengan rata-rata terbobot dengan peluangnya. Rumus untuk menghitung ragam adalah:

menghitung VaR kredit dengan asumsi nilai pinjaman terdistribusi normal untuk tingkat keyakinan 95 persen dan 99 persen adalah:

akan semakin besar, begitu pula dengan volatilitas, semakin besar volatilitas yang dihasilkan maka nila VaR akan semakin besar pula. Tingkat keyakinan 95 persen digunakan oleh Morgan "Risk Metrics" dan tingkat keyakinan 99 
persen digunakan oleh Basel Committee. Analisis VaR diawali dengan menentukan matriks transisi tahunan.

Matriks transisi diperoleh dari Desember 2015 sampai dengan Desember 2019 sehingga matriks transisi yang dihasilkan sebanyak 4 matriks yang berukuran 4 x 4 . Matriks transisi yang diperoleh dijumlah kemudian dicari rataratanya dan dari rata-rata yang diperoleh digunakan untuk menyusun matriks unconditional.

\section{Evaluasi Risiko Kredit}

Evaluasi risiko kredit dilakukan setelah mendapat data hasil dari analisis risiko kredit, membagi menjadi kredit lancar dan kredit bermasalah. Kredit bermasalah adalah semua kredit yang memiliki risiko tinggi karena debitur telah gagal/menghadapi masalah dalam memenuhi kewajiban yang telah ditentukan. Kemacetan kredit pada umumnya disebabkan oleh kesulitan kesulitan keuangan, baik yang disebabkan oleh faktor internal (manajemen) maupun faktor eksternal (Djumhana, 2000:82).

\section{Penanganan Risiko Kredit}

Penanganan Risiko Kredit adalah upaya - upaya yang ditempuh dalam menghadapi risiko, terdapat empat penanganan yang dapat dilakukan:
1. Menghindari risiko (risk avoidance);

2. Mitigasi risiko (risk reduction), dapat dilakukan dengan mengurangi kemungkinan atau dampaknya;

3. Transfer risiko kepada pihak ketiga (risk sharing);

4. Menerima risiko (risk acceptance)

\section{Pengaruh Manajemen Risiko Kredit Terhadap Kinerja}

Tahap terakhir adalah menganalisa pengaruh manajemen risiko kredit terhadap kinerja PT Bank Perkreditan Rakyat Sumatera Selatan. Dalam hal ini, akan dihitung penilaian PPAP terhadap rasio profitabilitas dimana akan berpengaruh langsung terhadap pendapatan bank. Penyisihan Penghapusan Aktiva Produktif (PPAP) adalah cadangan yang harus dibentuk sebesar persentase tertentu dari baki debet berdasarkan penggolongan kualitas Aktiva Produktif. PPAP mengacu pada PBI NO. 8/19/PBI/2006 tanggal 5 Oktober 2006, pasal 12 yang menerangkan:

- BPR wajib membentuk PPAP berupa PPAP umum dan PPAP khusus.

- PPAP umum ditetapkan paling kurang sebesar $0,5 \%$ (lima permil) dari Aktiva Produktif yang memiliki kualitas Lancar.

- PPAP khusus ditetapkan paling kurang sebesar

1. $10 \%$ dari Aktiva Produktif dengan kualitas Kurang Lancar setelah dikurangi dengan nilai agunan;

2. $50 \%$ dari Aktiva Produktif dengan kualitas Diragukan setelah dikurangi dengan nilai agunan;

3. $100 \%$ dari Aktiva Produktif dengan kualitas Macet setelah dikurangi dengan nilai agunan;

- BPR wajib melakukan penilaian atas agunan untuk mengetahui nilai ekonomisnya

Keharusan membentuk PPAP sesuai kualitas aktiva produktif (kolektibilitas), semakin jelek kualitas aktiva produktifnya semakin besar PPAP yang harus dibentuk. Setiap pembentukan PPAP akan menimbulkan beban PPAP yang secara langsung akan mengurangi laba bank atau bahkan berbalik menjadi kerugian apabila beban bank lebih besar dari pada pendapatan bank, sehingga dengan demikian bank akan selalu berusaha menjaga kualitas aktiva produktifnya, termasuk mendapatkan jaminan berupa agunan yang bernilai tinggi. 


\section{ANALISIS DAN PEMBAHASAN}

\section{Identifikasi Risiko Kredit PT BPR Sumsel Periode 2015 - 2019}

Berikut ini data mengenai identifikasi risiko kredit PT BPR periode

Tabel 1. Data Kolektibilitas PT BPR Sumsel periode 2015 - 2019 (Data Diolah)

(* dalam jutaan rupiah)

\begin{tabular}{crrrrrrrrrr}
\hline \multirow{2}{*}{$\begin{array}{c}\text { Kolek } \\
\text { tibilitas }\end{array}$} & \multicolumn{10}{c}{ Tahun } \\
\cline { 2 - 11 } & \multicolumn{1}{c}{2015} & \multicolumn{10}{c}{2016} & \multicolumn{1}{c}{2017} & \multicolumn{1}{c}{2018} & \multicolumn{2}{c}{2019} \\
\cline { 2 - 11 } $\mathbf{1}$ & 162.273 & 74,96 & 115.011 & 57,94 & 53.019 & 35,03 & 74.770 & 61,90 & 83.048 & 75,76 \\
$\mathbf{2}$ & 3.296 & 1,52 & 4.879 & 2,46 & 3.348 & 2,21 & 355 & 0,29 & 987 & 0,90 \\
$\mathbf{3}$ & 8.291 & 3,83 & 4.888 & 2,46 & 4.803 & 3,17 & 2.889 & 2,39 & 178 & 0,16 \\
$\mathbf{4}$ & 42.607 & 19,69 & 73.724 & 37,14 & 90.196 & 59,59 & 42.768 & 35,42 & 25.400 & 23,18 \\
\hline Total & $\mathbf{2 1 6 . 4 6 7}$ & $\mathbf{1 0 0}$ & $\mathbf{1 9 8 . 5 0 2}$ & $\mathbf{1 0 0}$ & $\mathbf{1 5 1 . 3 6 6}$ & $\mathbf{1 0 0}$ & $\mathbf{1 2 0 . 7 8 2}$ & $\mathbf{1 0 0}$ & $\mathbf{1 0 9 . 6 1 3}$ & $\mathbf{1 0 0}$ \\
\hline
\end{tabular}

Sumber: Laporan NPL Kredit PT BPR Sumsel Periode 2015 - 2019 (Data Diolah)

Tabel 2. Data NPL PT BPR Sumsel Periode 2015 - 2019 (Data Diolah)

(* dalam jutaan rupiah)

\begin{tabular}{crrrrrrrrrr}
\hline \multirow{2}{*}{ Loan } & \multicolumn{10}{c}{ Tahun } \\
\cline { 2 - 12 } & \multicolumn{2}{c}{2015} & \multicolumn{10}{c}{2016} & \multicolumn{1}{c}{2017} & 2018 & 2019 \\
\cline { 2 - 11 } & Nominal & $(\%)$ & Nominal & $(\%)$ & Nominal & $(\%)$ & Nominal & $(\%)$ & Nominal & $(\%)$ \\
\hline PL & 162.273 & 74,96 & 115.011 & 57,94 & 53.019 & 35,03 & 74.770 & 61,90 & 83.048 & 75,76 \\
NPL & $\mathbf{5 4 . 1 9 4}$ & $\mathbf{2 5 , 0 4}$ & $\mathbf{8 3 . 4 9 1}$ & $\mathbf{4 2 , 0 6}$ & $\mathbf{9 8 . 3 4 7}$ & $\mathbf{6 4 , 9 7}$ & $\mathbf{4 6 . 0 1 2}$ & $\mathbf{3 8 , 1 0}$ & $\mathbf{2 6 . 5 6 5}$ & $\mathbf{2 4 , 2 4}$ \\
\hline Total & 216.467 & 100 & 198.502 & 100 & 151.366 & 100 & 120.782 & 100 & 109.613 & 100 \\
\hline
\end{tabular}

Sumber: Laporan NPL Kredit PT. BPR Sumsel Periode 2015 - 2019 (Data Diolah)

Berdasarkan informasi yang didapatkan dari laporan NPL kredit PT BPR Sumsel tahun 2015 - 2019 yang dijelaskan tabel diatas, kredit bermasalah pada PT BPR Sumsel mengalami peningkatan dari tahun 2015 - 2017 kemudian menurun pada tahun 2018 - 2019.

Pada tahun 2015 dengan nominal NPL sebesar Rp 54.194 dan persentase NPL sebesar 25,04\%. Pada tahun ini, NPL sudah dalam kondisi waspada dikarenakan tingginya nilai kredit bermasalah pada PT BPR Sumsel.

Pada tahun 2016, nominal NPL mengalami peningkatan sebesar Rp 29.297 menjadi Rp 83.491 dan persentase NPL ikut meningkat sebesar $17,02 \%$ menjadi $42,06 \%$. Kenaikan NPL pada tahun ini dikarenakan tidak maksimalnya penagihan kredit sehingga banyak kredit lancar jatuh menjadi kredit bermasalah. Pada tahun 2016 juga PT BPR Sumsel mengalami pergantian direksi sehingga menyebabkan tidak maksimalnya penyaluran kredit yang diberikan dikarenakan banyak persetujuan kredit yang tidak diterima dan dibatalkan.

Pada tahun 2017, nominal NPL kembali mengalami peningkatan sebesar Rp 14.856 menjadi Rp 98.347 dan persentase NPL juga ikut meningkat sebesar 22,91\% menjadi $64,97 \%$. Makin tidak maksimalnya penagihan kredit dan kurang maksimalnya PT BPR Sumsel dalam melaksanakan restukturing dan rescheduling kredit menjadi penyebab utama NPL naik. Pengenaan sanksi dari OJK berupa penghentian penyaluran kredit (Stop Lending) sampai bulan Mei 2018 juga memperburuk nilai NPL pada tahun 2017 ini. 
Pada tahun 2018, nominal NPL mengalami penurunan sebesar Rp 52.425 menjadi Rp 46.012 dan persentase NPL ikut menurun sebesar $26,87 \%$ menjadi $38,10 \%$. Pemberian kredit yang telah menerapkan prinsip kehati - hatian juga beberapa cara seperti penagihan rutin menyebabkan penurunan NPL yang cukup signifikan pada tahun 2018.

Pada tahun 2019, nominal NPL kembali mengalami penurunan sebesar Rp 19.447 menjadi Rp 26.565 dan persentase NPL juga ikut menurun sebesar 13,86\% menjadi $24,24 \%$. Analisis kelayakan kredit yang telah berhasil menerapkan konsep 5C dalam penyaluran kredit serta penagihan rutin, restrukturisasi, penjadwalan ulang, penyitaan agunan, dan lelang jaminan menjadikan NPL kembali dapat ditekan walaupun nominalnya masih tinggi.
Non Performing Loan (NPL) adalah salah satu indikator kesehatan kredit suatu bank yang mampu memberikan informasi penilaian atas kondisi kredit pada bank umum maupun BPR. Berdasarkan Peraturan Bank Indonesia No 6/10/PBI/2004

mengenai Sistem Penilaian Tingkat Kesehatan Bank Umum dan BPR, menetapkan bahwa rasio kredit bermasalah (NPL) maksimal yakni sebesar 5\%. Dari hasil analisis perkembangan NPL pada PT BPR Sumsel bahwa perubahan persentase NPL disebabkan adanya perubahan berupa peningkatan dan penurunan nominal NPL. Berdasarkan data NPL periode 2015 2019, kondisi kesehatan kredit PT BPR Sumsel masih belum dapat dikatakan sehat karena masih melebihi standar maksimum yang ditetapkan oleh BI yaitu 5\%.

Analisis Risiko Kredit PT BPR Sumsel Periode 2015 - 2019 (Analisis Value at Risk VaR)

Matriks unconditional merupakan proporsi perubahan kolektibilitas debitur per bulan. Dengan matriks unconditional dapat diketahui peluang perubahan kolektibilitas debitur tiap bulan yang dapat dilihat dari perubahan nominal baki debet tiap bulannya. Matriks unconditional yang diperoleh adalah:

\begin{tabular}{lrrrr} 
& L & KL & D & M \\
& & & & \\
\hline L & 0,723 & 0,090 & 0 & 0 \\
& & & & \\
\hline KL & 0,089 & 0,545 & 0,184 & 0 \\
\hline D & 0 & 0,138 & 0,454 & 0,225 \\
& & & & \\
\hline M & 0 & 0 & 0,277 & 0,910
\end{tabular}

Keterangan: $\mathrm{L}=$ Lancar, $\mathrm{D}=$ Diragukan, $\mathrm{KL}=$ Kurang Lancar, $\mathrm{M}=$ Macet

Matriks di atas menunjukkan bahwa peluang kolektibilitas lancar untuk tetap bertahan pada posisinya adalah sebesar $0,723(72,3 \%)$. Nilai ini menunjukkan bahwa debitur yang memiliki kolektibilitas lancar memiliki peluang yang besar untuk tetap menjadi debitur yang dapat melaksanakan kewajibannya dalam membayar angsuran kredit dengan baik. Namun debitur kolektibilitas lancar memiliki peluang sebesar $0,090(9 \%)$ untuk dapat menjadi debitur dengan kolektibilitas kurang lancar. Hal ini menunjukkan bahwa PT BPR Sumsel harus berusaha untuk mempertahankan debitur dengan kolektibilitas lancar untuk tetap berada pada posisinya dan tidak berpindah ke kolektibilitas kurang lancar karena masih ada peluang sebesar 9\% bagi debitur kolektibilitas lancar berpindah ke kolektibilitas kurang lancar.

Debitur kolektibilitas kurang lancar memiliki peluang sebesar 0,089 (8,9\%) untuk pindah ke kolektibilitas lancar. 
Kolektibilitas kurang lancar untuk tetap bertahan pada kolektibilitas kurang lancar sebesar $0,545(54,5 \%)$ dan kolektibilitas kurang lancar untuk menjadi kolektibilitas diragukan sebesar $0,184(18,4 \%)$. Nilai ini menunjukkan BPR mengalami kerugian karena hanya sebesar $8,9 \%$ debitur yang berpindah ke kolektibilitas lancar sedangkan yang berpindah ke kolektibilitas diragukan lebih besar yaitu 18,4\% .

Peluang kolektibilitas diragukan menjadi kolektibilitas kurang lancar sebesar $0,138(13,8 \%)$, sedangkan peluang untuk tetap bertahan pada kolektibilitas diragukan sebesar 0,454 (45,4\%) dan kolektibilitas diragukan menjadi kolektibilitas macet sebesar 0,225 (22,5\%). Nilai tersebut menunjukkan bahwa kerugian yang ditimbulkan akibat keadaan ini cukup besar karena peluang berpindah ke kolektibilitas macet lebih besar dibandingkan peluang berpindah ke kolektibulitas kurang lancar. PT BPR Sumsel perlu menyiapkan suatu kegiatan untuk mengatasi keadaan ini.

Peluang untuk keluar dari kolektibilitas macet menjadi kolektibilitas diragukan sebesar 0,277 (27,7\%) dan peluang untuk tetap bertahan pada kolektibilitas macet sebesar 0,910 (91\%). Hal ini menunjukkan bahwa sebagian besar debitur dengan kolektibilitas macet tidak memiliki itikad untuk dapat keluar dari keadaan ini. Sikap debitur yang demikian membuat BPR mengalami kerugian yang cukup besar yang dapat mengganggu stabilitas keuangan BPR sehingga PT BPR Sumsel harus memiliki pengelolaan kredit yang baik. Hal ini disebabkan usaha debitur yang dibiayai oleh kredit mengalami kebangkrutan sehingga debitur tidak memiliki uang untuk membayar kredit, selain itu juga karena usaha sudah tidak ada debitur tidak mau melunasi utangnya.

Pergerakan VaR merupakan pergerakan nilai kerugian maksimum yang dapat dialami oleh bank untuk periode satu tahun pada tingkat keyakinan yang telah ditentukan. Dengan mengetahui pergerakan VaR pada kredit yang disalurkan maka akan diketahui berapa pergerakan kemungkinan kerugian maksimum yang dapat dialami bank sehingga dapat dilakukan pengelolaan risiko kredit yang sesuai

\section{Evaluasi Risiko Kredit PT BPR Sumsel Periode 2015 - 2019}

Dari identifikasi dan analisis risiko kredit sebelumnya, dapat dilihat bahwa PT BPR Sumsel belumlah memiliki manajemen risiko kredit yang baik. Hal itu dapat dilihat dari tingginya nilai NPL dan masih banyaknya pergerakan debitur dari berkolektibilitas lancar ke berkolektibilitas bermasalah. Evaluasi risiko kredit disini adalah menemukan hal - hal yang menjadi penyebab tingginya nilai kredit bermasalah. Beberapa permasalahan kredit bermasalah yang sering ditemukan pada PT BPR Sumsel dalam antara lain:

1. Beberapa agunan yang dijaminkan debitur pada tidak diikat secara sempurna sehingga menyulitkan untuk di eksekusi melalui lelang (termasuk yang tidak terpasang Hak Tanggungan)

2. Banyak jaminan yang nilainya kurang marketable atau lokasi kurang strategis sehingga kurang peminat / pembeli saat dilelang

3. Terdapat sebagian agunan yang nilai jaminannya saat ini tidak dapat mengcover / menutupi sisa kewajiban di BPR

4. Terdapat debitur dan pemilik jaminan yang sudah meninggal dunia, namun tidak dicover asuransi jiwa

Permasalahan - permasalahan inilah yang menjadi titik lemah manajemen risiko pada PT BPR Sumsel dimana bagian kredit masih sangat lemah dalam melakukan analisis kredit.

\section{Penanganan Risiko Kredit PT BPR Sumsel Periode 2015 - 2019}

Dari hasil evaluasi, PT BPR Sumsel pada awalnya belum memiliki manajemen risiko yang baik namun dengan sejalannya 
waktu PT BPR Sumsel telah dapat mengurangi risiko kredit yang dihadapi. PT BPR Sumsel tentunya harus memiliki penanganan risiko kredit yang baik agar risiko kredit yang terjadi dapat diminimalisir. Penanganan risiko kredit yang baik dan benar dapat menurunkan rasio NPL yang terjadi. Penanganan risiko kredit yang sudah dilakukan oleh PT BPR Sumsel antara lain:

1. Pembinaan dan penagihan intensif dilakukan terhadap debitur yang masuk dalam daftar kelompok kredit bermasalah.

2. Penjadwalan ulang angsuran atau memberi perpanjangan waktu angsuran dan jatuh tempo.

3. Restrukturisasi atau metode melakukan evaluasi dan pengubahan pokok pinjaman, jangka waktu, sistem angsuran, dan besarnya agunan.

4. Penyitaan agunan. Apabila ketiga cara di atas tidak membuahkan hasil, maka pihak PT BPR Sumsel mengambil tindakan tegas berupa pelelangan agunan

Kinerja PT BPR Sumsel Periode 2015 2019

Kinerja PT BPR Sumsel periode 2015 - 2019 pada penelitian ini diukur dengan menggunakan PPAP. Penyisihan

Tabel 3. Data PPAP PT BPR Sumsel periode 2015 - 2019 (Data Diolah)

\begin{tabular}{ccccr} 
Tahun & $\begin{array}{c}\text { Kredit Yang } \\
\text { Diberikan }\end{array}$ & $\begin{array}{c}\text { Nilai } \\
\text { Pengurang }\end{array}$ & $\begin{array}{c}\text { Nilai } \\
\text { Netto }\end{array}$ & PPAP \\
\hline 2015 & 216.467 & 250.112 & 237.124 & $\mathbf{1 2 . 9 8 8}$ \\
2016 & 198.502 & 219.416 & 201.593 & $\mathbf{1 7 . 8 2 3}$ \\
2017 & 151.366 & 150.787 & 112.381 & $\mathbf{3 8 . 4 0 6}$ \\
2018 & 120.782 & 138.653 & 115.356 & $\mathbf{2 3 . 2 9 7}$ \\
2019 & 109.613 & 164.435 & 154.505 & $\mathbf{9 . 9 3 0}$ \\
\hline
\end{tabular}

Sumber: Laporan Keuangan PT BPR Sumsel Periode 2015 - 2019 (Data Diolah)

Nilai pengurang adalah nilai agunan yang diperhitungkan sebagai pengurang dalam pembentukan PPAP, sedangkan nilai netto adalah nilai bersih yang didapatkan dari nilai agunan tersebut. PPAP didapatkan
Penghapusan Aktiva Produktif (PPAP) adalah cadangan yang harus dibentuk sebesar persentase tertentu dari baki debet berdasarkan penggolongan kualitas Aktiva Produktif. PPAP mengacu pada PBI NO. 8/19/PBI/2006 tanggal 5 Oktober 2006, pasal 12 yang menerangkan:

- BPR wajib membentuk PPAP berupa PPAP umum dan PPAP khusus.

- PPAP umum ditetapkan paling kurang sebesar $0,5 \%$ (lima permil) dari Aktiva Produktif yang memiliki kualitas Lancar.

- PPAP khusus ditetapkan paling kurang sebesar

1. $10 \%$ dari Aktiva Produktif dengan kualitas Kurang Lancar setelah dikurangi dengan nilai agunan;

2. $50 \%$ dari Aktiva Produktif dengan kualitas Diragukan setelah dikurangi dengan nilai agunan;

3. $100 \%$ dari Aktiva Produktif dengan kualitas Macet setelah dikurangi dengan nilai agunan; Berikut ini data mengenai kinerja PT BPR periode 2015 - 2019 dengan PPAP: dari selisih nilai pengurang dengan nilai netto.

Berdasarkan tabel diatas dapat dilihat ketika posisi PPAP pada periode 2015 - 2019. Pada tahun 2015, kredit yang 
diberikan berada pada posisi Rp 216.467 dibentuk PPAP sebesar Rp 12.988 dengan nilai pengurang $\operatorname{Rp} 250.112$ dan nilai netto Rp 237.124. Pada tahun ini, PPAP yang dibentuk masih dalam jumlah yang rendah sehingga PT BPR Sumsel masih bisa mendapatkan laba.

Pada tahun 2016, dengan kredit yang diberikan menurun sebesar Rp 17.965 menjadi Rp 198.502 diperoleh nilai PPAP yang mengalami peningkatan sebesar $\mathrm{Rp}$ 4.835 menjadi $\mathrm{Rp} 17.823$ dengan nilai pengurang $\mathrm{Rp} 219.416$ dan nilai netto $\mathrm{Rp}$ 201.593. Pada tahun ini, PPAP yang dibentuk mulai menunjukkan peningkatan sehingga berpengaruh negatif pada PT BPR Sumsel yang ditandai dengan kerugian pada kinerjanya.

Pada tahun 2017, kredit yang diberikan kembali menurun sebesar Rp 47.136 menjadi Rp 151.366 diperoleh nilai PPAP yang mengalami peningkatan sebesar Rp 20.583 menjadi Rp 38.406 dengan nilai pengurang $\mathrm{Rp} 150.787$ dan nilai netto $\mathrm{Rp}$ 112.381. Pada tahun ini, terdapat koreksi penambahan cadangan PPAP berdasarkan hasil pemeriksaan OJK dan KAP yang menyebabkan kinerja PT BPR Sumsel mengalami kerugian yang lumayan besar.

Pada tahun 2018, kredit yang diberikan terus menurun sebesar Rp 30.584 menjadi Rp 120.782 diperoleh nilai PPAP yang mengalami penurunan sebesar $\mathrm{Rp}$ 15.109 menjadi $\mathrm{Rp} 23.297$ dengan nilai pengurang $\mathrm{Rp} 138.653$ dan nilai netto $\mathrm{Rp}$ 115.356. Pada tahun ini, PPAP telah mulai dapat ditekan dibandingkan tahun sebelumnya namun kinerja masih menunjukkan penurunan yang ditandai dengan masih meruginya PT BPR Sumsel.

Pada tahun 2019, kredit yang diberikan menurun kembali sebesar Rp 11.169 menjadi Rp 109.613 diperoleh nilai PPAP yang mengalami penurunan sebesar Rp 13.367 menjadi Rp 9.930 dengan nilai pengurang $R p 164.435$ dan nilai netto $R p$ 154.505. Pada tahun ini, PT BPR Sumsel dapat menekan PPAP sehingga berturun drastis yang berpengaruh pada kinerjanya sehingga akhirnya dapat menghasilkan laba kembali setelah 3 tahun sebelumnya menderita kerugian.

\section{Analisis Pengaruh Manajemen Risiko Kredit Terhadap Kinerja PT BPR Sumsel Periode $2015-2019$}

Berikut ini data mengenai pengaruh manajemen risiko kredit terhadap kinerja pada PT BPR Sumsel periode 2015 - 2019.

Tabel 4. Data Kredit Yang Diberikan, NPL, PPAP, dan Laba/Rugi PT BPR Sumsel periode 2015 - 2019 (Data Diolah)

\begin{tabular}{rrrrrr} 
& & \multicolumn{4}{c}{$(*$ dalam jutaan rupiah) } \\
\hline \multirow{2}{*}{ Tahun } & Kredit Yang & \multicolumn{2}{c}{ NPL } & PPAP & Laba/ \\
\cline { 3 - 4 } & Diberikan & Nominal & $(\%)$ & & Rugi \\
\hline 2015 & 216.467 & 54.194 & 25,04 & $\mathbf{1 2 . 9 8 8}$ & $\mathbf{6 . 3 3 8}$ \\
2016 & 198.502 & 83.491 & 42,06 & $\mathbf{1 7 . 8 2 3}$ & $\mathbf{( 4 . 6 4 7 )}$ \\
2017 & 151.366 & 98.347 & 64,97 & $\mathbf{3 8 . 4 0 6}$ & $\mathbf{( 8 . 2 3 2 )}$ \\
2018 & 120.782 & 46.012 & 38,10 & $\mathbf{2 3 . 2 9 7}$ & $\mathbf{( 6 . 9 5 9 )}$ \\
2019 & 109.613 & 26.565 & 24,24 & $\mathbf{9 . 9 3 0}$ & $\mathbf{5 . 1 2 3}$ \\
\hline
\end{tabular}

Sumber: Laporan Keuangan PT BPR Sumsel Periode 2015 - 2019 (Data Diolah)

Berdasarkan tabel diatas dapat dilihat ketika NPL dan PPAP pada PT BPR Sumsel mengalami keterkaitan. Pada tahun 2015, ketika nominal NPL berada pada posisi $\mathrm{Rp} 54.194$ dengan persentase 25,04\%, PPAP yang dibentuk sebesar Rp
12.988 dengan memperoleh laba sebesar Rp 6.338 .

Pada tahun 2016, NPL meningkat sebesar Rp 29.297 menjadi Rp 83.491 dengan peningkatan persentase sebesar $17,02 \%$ menjadi $42,06 \%$. PPAP yang 
dibentuk juga meningkat sebesar Rp 4,835 menjadi Rp 17.823 diakibatkan banyaknya kredit bermasalah dan macet. Kenaikan PPAP akibat menunggaknya kredit mengakibatkan tergerusnya keuntungan sehingga mengakibatkan kerugian sebesar Rp (4.647). Pada tahun 2016 juga PT BPR Sumsel mengalami pergantian direksi sehingga menyebabkan tidak maksimalnya penyaluran kredit yang diberikan dikarenakan banyak persetujuan kredit yang tidak diterima dan dibatalkan.

Pada tahun 2017, NPL kembali meningkat tajam sebesar $22,91 \%$ menjadi $64,97 \%$ dengan peningkatan nominal sebesar Rp 14.856 menjadi Rp 98.347. PPAP juga meningkat tajam sebesar Rp 20.583 menjadi Rp 38.406 dan PT BPR Sumsel mengalami kerugian sampai Rp (8.232). Terdapat beberapa macam hal yang mempengaruhinya seperti koreksi penambahan cadangan PPAP hasil pemeriksaan OJK dan KAP serta pengenaan sanksi dari OJK berupa penghentian penyaluran kredit (Stop Lending) sampai bulan Mei 2018.

Pada tahun 2018, NPL mengalami penurunan sebesar $26,87 \%$ menjadi $38,10 \%$ dengan penurunan nominal sebesar $\mathrm{Rp}$ 52.335 menjadi Rp 46.012. PPAP juga mengalami penurunan sebesar Rp 15.109 menjadi Rp 23.297 walaupun PT BPR Sumsel masih merugi sebesar Rp (6.959). Pemberian kredit yang telah menerapkan prinsip kehati - hatian juga beberapa cara seperti penagihan rutin menjadikan tahun 2018 PT BPR Sumsel dapat mengalami rebound dalam kinerjanya.

Pada tahun 2019, NPL mengalami penurunan kembali sebesar 13,86\% menjadi $24,24 \%$ disertai penurunan nominal sebesar Rp 19.447 menjadi Rp 26.565. PPAP kembali turun sebesar Rp 13.367 menjadi Rp 9.930 dan laba akhirnya dapat diraih sebesar Rp 5.123. Penagihan rutin, restrukturisasi, penjadwalan ulang, penyitaan agunan, dan lelang jaminan menjadi solusi manajemen risiko kredit yang tepat yang mengantarkan PT BPR
Sumsel berhasil meraih laba setelah 3 tahun sebelumnya mengalami kerugian.

\section{Pengaruh Manajemen Risiko Kredit Terhadap Kinerja PT BPR Sumsel Periode 2015 - 2019}

Manajemen risiko kredit yang baik adalah ketika analisis kelayakan kredit telah berhasil menerapkan konsep 5C dalam penyaluran kredit serta melakukan mitigasi risiko kredit seperti penagihan rutin, restrukturisasi, penjadwalan ulang, penyitaan agunan, dan lelang jaminan sehingga dapat menghasilkan kredit yang berkualitas dalam hal ini kredit lancar (performing loan) dan menekan angka kredit bermasalah (non performing loan) sekecil - kecilnya yang akhirnya akan berpengaruh pada kinerja pendapatan.

Dari hasil analisis pengaruh manajemen risiko kredit terhadap kinerja pada PT BPR Sumsel periode 2015 - 2019 menunjukkan bahwa pada tahun 2015 2017 dengan manajemen risiko yang tidak baik berpengaruh negatif pada kinerja PT BPR Sumsel, yaitu meningkatnya PPAP dan berkurangnya pendapatan. Pada tahun 2018 - 2019 dengan manajemen risiko yang baik tentunya berpengaruh positif pada kinerja PT BPR Sumsel, ditandai dengan menurunnya PPAP dan meningkatnya pendapatan.

Kesimpulannya adalah bahwa manajemen risiko kredit yang baik berpengaruh positif dan signifikan pada kinerja PT BPR Sumsel, dalam hal ini adalah PPAP dan laba. Hasil penelitian tentang pengaruh manajemen risiko terhadap kinerja keuangan ternyata sejalan dengan beberapa penelitian terdahulu, seperti yang dilakukan Caya (2010:77) menunjukan bahwa pengaruh penerapan manajemen risiko perbankan terhadap pemberian kredit menunjukkan hasil yang signifikan. Hal serupa juga dinyatakan oleh Poudel (2012:102) bahwa manajemen risiko kredit yang diukur dengan default rate yang diproksikan dengan non performing loan (NPL) berpengaruh negatif signifikan terhadap kinerja yang berarti 
bahwa manajemen risiko akan berpengaruh positif pada kinerja keuangan. Kemudian oleh Attar dkk, (2014:115) dalam penelitiannya menemukan bahwa penerapan manajemen risiko kredit dan manajemen risiko operasional berpengaruh positif dan signifikan terhadap kinerja keuangan

\section{KESIMPULAN DAN SARAN}

\subsection{Kesimpulan}

Penelitian ini dilakukan untuk menganalisis pengaruh manajemen risiko kredit terhadap kinerja PT Bank Perkreditan Rakyat Sumatera Selatan periode 2015 2019, yang dapat disimpulkan sebagai berikut:

1. Hasil penelitian tentang identifikasi risiko kredit PT BPR Sumsel periode 2015 - 2019 yang berdasarkan pada data NPL, menyatakan bahwa kondisi kesehatan kredit PT BPR Sumsel masih belum dapat dikatakan sehat karena masih melebihi standar maksimum yang ditetapkan oleh OJK yaitu 5\%.

2. Hasil penelitian tentang analisis risiko kredit PT BPR Sumsel periode 2015 2019 dengan metode VaR menerangkan bahwa perpindahan kolektibilitas didominasi oleh pergerakan dari kolektibilitas kredit lancar menuju kredit macet yang berakibat tingginya NPL dan penurunan pendapatan BPR.

3. Hasil penelitian tentang evaluasi risiko kredit PT BPR Sumsel periode 2015 2019 menjelaskan bahwa PT BPR Sumsel belumlah memiliki manajemen risiko kredit yang baik. Terdapat beberapa faktor - faktor yang menyebabkan permasalahan bahkan kegagalan dalam pengembalian kredit namun kebanyakan diakibatkan oleh agunan / jaminan, seperti pengikatan tidak sempurna, kurang marketable, dan tidak mengcover kewajiban di BPR.

4. Hasil penelitian tentang penanganan risiko kredit PT BPR Sumsel periode 2015 - 2019 menjelaskan beberapa langkah yang telah ditempuh PT BPR
Sumsel dalam menangani risiko kredit seperti pembinaan dan penagihan intensif, penjadwalan ulang, restrukturisasi, serta penyitaan agunan.

5. Hasil penelitian tentang pengaruh manajemen risiko kredit terhadap kinerja PT BPR Sumsel periode 2015 2019 yang diukur melalui PPAP bahwa PPAP berpengaruh terhadap pendapatan BPR. NPL yang tinggi pada PT BPR Sumsel tentunya akan menimbulkan beban PPAP yang secara langsung akan mengurangi laba BPR atau bahkan berbalik menjadi kerugian apabila beban BPR lebih besar dari pada pendapatan BPR

SaranAdapun saran dalam penelitian ini adalah sebagai berikut:

- Bagi Manajemen PT BPR Sumsel

Bagi PT BPR Sumsel agar benar - benar dapat memperhatikan manajemen risiko kredit, karena dengan manajemen risiko kredit yang baik dan terstruktur tentunya masalah risiko kredit terutama kredit bermasalah dapat berkurang. Meningkatkan pelaksanaan prinsip kehati - hatian, melakukan monitoring yang lebih intensif, dan melakukan pengawasan \& pembinaan kepada debitur adalah beberapa cara yang dapat dilakukan untuk mengatasi risiko kredit.

- Bagi Penelitian Selanjutnya

Bagi peneliti yang akan meneliti kasus yang sama dimasa yang akan datang, diharapkan agar menambah periode waktu penelitian yang digunakan sehingga bisa lebih panjang dikarenakan PT BPR Sumsel yang baru berusia 12 tahun dan memiliki history kredit yang sangat menarik untuk diteliti dari awal sehingga nantinya akan memperoleh gambaran yang lebih luas dan mendalam tentang kondisi dari penyaluran kredit pada PT BPR Sumsel mengingat BPR adalah Bank Perkreditan Rakyat sehingga berfokus pada perkreditan

\section{DAFTAR PUSTAKA}

Attar, dkk. 2014. Pengaruh Penerapan Manajemen Risiko Terhadap Kinerja Keuangan Perbankan yang Terdaftar Di Bursa Efek Indonesia. Pascasarjana 
Universitas Syiah Kuala. (diakses 11 April 2020)

Djohanputro, Bramantyo. 2008 . Manajemen Risiko Korporat. Jakarta: Penerbit PPM

Djumhana, Muhamad. 2000. Hukum Perbankan di Indonesia. Bandung: PT Citra Aditya Bakti

Namirah, Riska. 2013. Analisis Penerapan Manajemen Risiko dan Pengaruhnya Terhadap Kinerja Laba Pada Bank Pembangunan Indonesia (BPD) Se-Indonesia Tahun 2008 - 2012. Fakultas Ekonomi dan Bisnis Universitas Hasanuddin Makassar. (diakses 20 April 2020)

Poudel, Ravi Prakash. 2012. Corporate Governance and Efficiency in Nepalese Commercial Banks

Prabaswara, Pranadhipa Caya. 2010. Analisis Manajemen Risiko Kredit Pada PT. Bank Perkreditan Rakyat Gamping Artha Raya. Fakultas Ekonomi Universitas Islam Indonesia Yogyakarta. (diakses 9 April 2020)

Rachman, Dwi Kurnia. 2011. Analisis Manajemen Risiko Kredit Bermasalah Pada Produk Kredit Masyarakat Desa Di Bank X Bogor. Fakultas Ekonomi dan Manajemen Institut Pertanian Bogor. (diakses 10 April 2020)

Wildah, Andriani. 2014. Analisis Pengaruh Penerapan Basel Capital Accord Dan Good Corporate Governance Terhadap Manajemen Risiko Pada Perbankan Indonesia Yang Terdaftar Di Bursa Efek Indonesia. Fakultas Ekonomi Universitas Widyatama Bandung. (diakses 22 April 2020) www.bi.go.id (diakses 3 April 2020)

www.ojk.go.id (diakses 3 April 2020) 